\title{
Outdoor and Indoor Cultivation of Spirulina platensis in the Extreme South of Brazil
}

\author{
Michele R. Andrade and Jorge A. V. Costa* \\ Laboratório de Engenharia Bioquímica, Departamento de Química, Fundação Universidade \\ Federal do Rio Grande, Caixa Postal 474, CEP 96201-900, Rio Grande, RS, Brazil. \\ Fax: +55-53-32338745. E-mail: dqmjorge@furg.br
}

* Author for correspondence and reprint requests

Z. Naturforsch. 63c, 85-90 (2008); received June 4/July 26, 2007

Water supplemented with $10 \%$ or $20 \%(\mathrm{v} / \mathrm{v})$ of Zarrouk medium was used to cultivate Spirulina platensis in closed and open bioreactors under controlled conditions $\left(30^{\circ} \mathrm{C}\right.$, $32.5 \mu \mathrm{mol} \mathrm{m}{ }^{-2} \mathrm{~s}^{-1}, 12 \mathrm{~h}$ light/dark photoperiod) and in a greenhouse $\left(9.4\right.$ to $46^{\circ} \mathrm{C}$, up to $2800 \mu \mathrm{mol} \mathrm{m} \mathrm{m}^{-2} \mathrm{~s}^{-1}$, variable day length photoperiod) using different initial biomass concentrations $\left(X_{0}\right)$ in the extreme south of Brazil $\left(32.05^{\circ} \mathrm{S}, 52.11^{\circ} \mathrm{W}\right)$. Under controlled conditions the maximum specific growth rate $\left(\mu_{\max }\right)$ was $0.102 \mathrm{~d}^{-1}$, the biomass doubling time $\left(t_{\mathrm{d}}\right)$ was $6.8 \mathrm{~d}$, the maximum dry biomass concentration $\left(X_{\max }\right)$ was $1.94 \mathrm{~g} \mathrm{~L}^{-1}$ and the maximum productivity $\left(P_{\max }\right)$ was $0.059 \mathrm{~g} \mathrm{~L}^{-1} \mathrm{~d}^{-1}$, while the corresponding values in the greenhouse experiments were $\mu_{\max }=0.322 \mathrm{~d}^{-1}, t_{\mathrm{d}}=2.2 \mathrm{~d}, X_{\max }=1.73 \mathrm{~g} \mathrm{~L}^{-1}$ and $P_{\max }=0.112 \mathrm{~g} \mathrm{~L}^{-1} \mathrm{~d}^{-1}$. Under controlled conditions the highest values for these parameters occurred when $X_{0}=$ $0.15 \mathrm{~g} \mathrm{~L}^{-1}$, while in the greenhouse $X_{0}=0.4 \mathrm{~g} \mathrm{~L}^{-1}$ produced the highest values. These results show that the cultivation of S. platensis in greenhouses in the extreme south of Brazil is technically viable and that the $S$. platensis inoculum and the concentration of Zarrouk medium can be combined in such a way as to obtain growth and productivity parameters comparable, or superior, to those occurring in bioreactors under controlled conditions of temperature, illuminance and photoperiod.

Key words: Bioreactor, Southern Brazil, Spirulina platensis

\section{Introduction}

The use of the solar energy to cultivate photosynthetic microorganisms has become of increasing interest to researchers and investors. One of the most studied photosynthetic microorganisms is Spirulina, which is produced worldwide due to its nutritional and therapeutic properties and the fact that its dehydrated biomass can be used as a human or animal dietary supplement.

The growth of photosynthetic microorganisms is influenced by factors such as the susceptibility of the culture to evaporation and contamination (Vonshak and Richmond, 1988), type and intensity of agitation (Hosaka et al., 1995), temperature, illuminance, duration of the photoperiod, i.e. light/ dark cycles (Hase et al., 2000) and illuminance gradients within bioreactors (Grima et al., 1996).

Closed bioreactors facilitate temperature control and reduce, or eliminate, contamination (Travieso et al., 2001; Torzillo et al., 1986); illuminance can be improved in flat-plate bioreactors (Richmond et al., 2003) or when the concentration of cells is low (Chen et al., 1997). However, open bio- reactors are most often used for the large-scale cultivation of photosynthetic microorganisms (Jiménez et al., 2003; Belay, 1997) because such reactors use solar energy for heat and light and are cheap to construct and simple to operate, although the productivity of such systems is generally low.

Open bioreactors exposed to natural environmental conditions are subject to the prevailing climatic conditions that can influence the growth of the target microorganism and can limit cultivation to the hottest months of the year, making it important to evaluate the climatic potential of areas with regard to the production of photosynthetic microorganisms (Jiménez et al., 2003; Hase et al., 2000). Furthermore, Hase et al. (2000) have pointed out that covered bioreactors with a structure like a greenhouse can be a low-cost alternative which can compensate for negative environmental effects such as low temperature.

Nutrient costs are also an important factor in the production of Spirulina biomass (Vonshak, 1997), and the reduction of such costs without a decrease in productivity can ensure that culturing 
Spirulina biomass is economically viable. Zarrouk medium (Zarrouk, 1966) was formulated for the cultivation of Spirulina; however it has been reported that maximum Spirulina biomass productivity occurred in open tank bioreactors using 20\% (v/v) Zarrouk medium (Radmann et al., 2007).

Several Spirulina strains can grow between 12 and $43{ }^{\circ} \mathrm{C}$, and the temperature optimum for growth is between 30 and $38^{\circ} \mathrm{C}$ (Belay, 1997; Tomaselli et al., 1993). In the extreme south of Brazil, a subtropical area, temperatures within the optimal range for the growth of Spirulina usually occur from December to March (summer in the southern hemisphere); in the other months temperatures can be less than $12^{\circ} \mathrm{C}$. The objective of the work described in this paper was to evaluate the cultivation of Spirulina platensis in open and closed bioreactors situate in the extreme south of Brazil and to assess the influence of the nutrient concentration and initial $S$. platensis biomass concentration.

\section{Material and Methods}

We cultivated Spirulina platensis strain LEB-52 (Costa et al., 2004) in tap water supplemented with $10 \%$ or $20 \%(\mathrm{v} / \mathrm{v})$ of Zarrouk medium (Zarrouk, 1966). Cultures were accomplished in two sets of bioreactors: in closed $2 \mathrm{~L}$ Erlenmeyer flasks with an $1.8 \mathrm{~L}$ working volume, agitated by sterile air bubbling; and in $6 \mathrm{~L}$ acrylic open raceway bioreactors, agitated by acrylic paddles rotating at 18 revs $\min ^{-1}$. For both sets of bioreactors we used two environmental conditions: One set of the bioreactors was placed in a growth chamber at $30^{\circ} \mathrm{C}$, illuminated with $32.5 \mu \mathrm{mol} \mathrm{m} \mathrm{m}^{-2} \mathrm{~s}^{-1}$ using $40 \mathrm{~W}$ daylight-type fluorescent lamps (Osram, São Paulo, Brazil) under a $12 \mathrm{~h}$ light/dark photoperiod (Costa et al., 2000); while the other set of bioreactors was placed in an outdoor greenhouse, protected from UV light, and exposed to the natural environmental conditions prevailing in the extreme south of Brazil $\left(32.05^{\circ} \mathrm{S}, 52.11^{\circ} \mathrm{W}\right)$ during May and June of 2004. The initial biomass concentration was $0.15 \mathrm{~g} \mathrm{~L}^{-1}$ or $0.40 \mathrm{~g} \mathrm{~L}^{-1}$, and the cultures were maintained until the death phase or until a maximum of $50 \mathrm{~d}$. The volume of the media in the open bioreactors was maintained constant by the daily replacement of the water lost by evaporation. Each experiment was replicated.

For each bioreactor type the cultures were carried out according to a complete factorial $2^{3}$ design
(Box et al., 1978) in which the factors were the content of Zarrouk medium (10\% and $20 \% \mathrm{v} / \mathrm{v})$, the initial biomass concentration $\left(X_{0}=0.15 \mathrm{~g} \mathrm{~L}^{-1}\right.$ and $0.4 \mathrm{~g} \mathrm{~L}^{-1}$ ) and the environmental conditions (controlled in a growth chamber at $30^{\circ} \mathrm{C}$, $32.5 \mu \mathrm{mol} \mathrm{m}^{-2} \mathrm{~s}^{-1}$ and $12 \mathrm{~h} \mathrm{light/dark} \mathrm{photoperiod}$ and uncontrolled in a greenhouse under prevailing environmental conditions). The S. platensis biomass concentration was determined every $24 \mathrm{~h}$ by measuring the optical density of the cultures at $670 \mathrm{~nm}$ and comparing the values to previously prepared standard curves of optical density versus biomass (Costa et al., 2002). The maximum and minimum temperatures of the air inside the greenhouse were registered daily by a digital thermometer and the illuminance was determined at the surface of the open cultures using a MLM 1332 digital lightmeter (Minipa, Brazil).

At the end of each run the $S$. platensis biomass $(X)$ values were used to calculate the maximum specific growth rate $\left(\mu_{\max }, \mathrm{d}^{-1}\right)$ by the exponential regression of the logarithmic growth phase of the curve produced by a plot of biomass versus time. The biomass doubling time $\left(t_{\mathrm{d}}, \mathrm{d}\right)$ was calculated using natural logarithms $(\ln )$ as $t_{\mathrm{d}}=\ln 2 / \mu_{\max }$ (Bailey and Ollis, 1986). The maximum S. platensis biomass concentration $\left(X_{\max }, \mathrm{g} \mathrm{L}^{-1}\right.$ ) was also recorded and the maximum productivity $\left(P_{\max }\right.$, $\left.\mathrm{g} \mathrm{L}^{-1} \mathrm{~d}^{-1}\right)$ calculated from the equation $P=\left(X_{\mathrm{t}}-\right.$ $\left.X_{0}\right) /\left(t-t_{0}\right)$, where $X_{\mathrm{t}}$ is the biomass concentration $\left(\mathrm{g} \mathrm{L}^{-1}\right)$ at time $t(\mathrm{~d})$ and $X_{0}$ the initial biomass concentration $\left(\mathrm{g} \mathrm{L}^{-1}\right)$ at $t_{0}$ (Schmidell et al., 2001). All results were submitted to analysis of variance (ANOVA) at the $90 \%$ confidence interval $(p<0.1)$.

\section{Results and Discussion}

The highest maximum specific growth rate $\left(\mu_{\max }\right)$ for cultures growing under controlled conditions was $0.102 \mathrm{~d}^{-1}$ in open bioreactors containing water supplemented with $10 \%$ Zarrouk medium and inoculated with $0.15 \mathrm{~g} \mathrm{~L}^{-1}$ of $S$. platensis biomass, giving a biomass doubling time $\left(t_{\mathrm{d}}\right)$ of $6.8 \mathrm{~d}$ (Table I). Under controlled conditions and irrespective of the bioreactor type, $\mu_{\max }$ was always higher for the $10 \%$ Zarrouk medium cultures than for the $20 \%$ Zarrouk medium cultures (Table I). The initial $S$. platensis biomass concentration of the inoculum $\left(X_{0}\right)$ did not significantly alter the value of $\mu_{\max }$ in closed bioreactors under controlled conditions, but in open bioreactors $\mu_{\max }$ de- 
Table I. Growth conditions and kinetic and productivity data for Spirulina platensis growing in water supplemented with $10 \%$ or $20 \%(\mathrm{v} / \mathrm{v})$ Zarrouk medium in closed bioreactors and raceway bioreactors under controlled conditions $\left(30{ }^{\circ} \mathrm{C}, 32.5 \mu \mathrm{mol} \mathrm{m}{ }^{-2} \mathrm{~s}^{-1}, 12 \mathrm{~h}\right.$ light/dark photoperiod) and in a greenhouse $\left(9.4\right.$ to $46{ }^{\circ} \mathrm{C}$, up to $2800 \mu \mathrm{mol} \mathrm{m}^{-2} \mathrm{~s}^{-1}$, variable day length photoperiod), initial biomass concentration $\left(X_{0}\right)$ of 0.15 or $0.40 \mathrm{~g} \mathrm{~L}^{-1}$. The parameters evaluated (mean \pm standard deviation) were the maximum specific growth rate $\left(\mu_{\max }, \mathrm{d}^{-1}\right)$, biomass doubling time $\left(t_{\mathrm{d}}, \mathrm{d}\right)$, maximum biomass concentration $\left(X_{\max }, \mathrm{g} \mathrm{L}^{-1}\right)$ and maximum productivity $\left(P_{\max }, \mathrm{g} \mathrm{L}^{-1} \mathrm{~d}^{-1}\right)$.

\begin{tabular}{|c|c|c|c|c|}
\hline $\begin{array}{l}\text { Content }(\% \mathrm{v} / \mathrm{v}) \text { of Zarrouk medium }(\mathrm{ZM}) \\
\text { and inoculum size }\left(X_{0}\left[\mathrm{~g} \mathrm{~L}^{-1}\right]\right)\end{array}$ & $\mu_{\max }\left[\mathrm{d}^{-1}\right]$ & $t_{\mathrm{d}}[\mathrm{d}]^{\mathrm{a}}$ & $X_{\max }\left[\mathrm{g} \mathrm{L}^{-1}\right]$ & $P_{\max }\left[\mathrm{g} \mathrm{L}^{-1} \mathrm{~d}^{-1}\right]$ \\
\hline $\begin{array}{l}\text { Controlled conditions, closed bioreactors } \\
10 \% \mathrm{ZM}, X_{0}=0.15 \\
20 \% \mathrm{ZM}, X_{0}=0.15 \\
10 \% \mathrm{ZM}, X_{0}=0.4 \\
20 \% \mathrm{ZM}, X_{0}=0.4\end{array}$ & $\begin{array}{l}0.075 \pm 0.001 \\
0.059 \pm 0.009 \\
0.081 \pm 0.009 \\
0.057 \pm 0.021\end{array}$ & $\begin{array}{r}9.2 \\
11.8 \\
8.6 \\
12.2\end{array}$ & $\begin{array}{l}1.79 \pm 0.17 \\
1.94 \pm 0.23 \\
0.89 \pm 0.04 \\
1.27 \pm 0.01\end{array}$ & $\begin{array}{l}0.056 \pm 0.002 \\
0.059 \pm 0.004 \\
0.040 \pm 0.002 \\
0.037 \pm 0.001\end{array}$ \\
\hline $\begin{array}{l}\text { Controlled conditions, open bioreactors } \\
10 \% \text { ZM, } X_{0}=0.15 \\
20 \% \text { ZM, } X_{0}=0.15 \\
10 \% \text { ZM, } X_{0}=0.4 \\
20 \% \text { ZM, } X_{0}=0.4\end{array}$ & $\begin{array}{l}0.102 \pm 0.001 \\
0.082 \pm 0.003 \\
0.053 \pm 0.004 \\
0.031 \pm 0.002\end{array}$ & $\begin{array}{r}6.8 \\
8.5 \\
13.1 \\
22.4\end{array}$ & $\begin{array}{l}1.21 \pm 0.07 \\
1.55 \pm 0.19 \\
0.85 \pm 0.01 \\
1.07 \pm 0.11\end{array}$ & $\begin{array}{l}0.047 \pm 0.004 \\
0.057 \pm 0.003 \\
0.039 \pm 0.000 \\
0.047 \pm 0.001\end{array}$ \\
\hline $\begin{array}{l}\text { Greenhouse conditions, closed bioreactors } \\
10 \% \mathrm{ZM}, X_{0}=0.15 \\
20 \% \mathrm{ZM}, X_{0}=0.15 \\
10 \% \mathrm{ZM}, X_{0}=0.4 \\
20 \% \mathrm{ZM}, X_{0}=0.4\end{array}$ & $\begin{array}{l}0.257 \pm 0.001 \\
0.322 \pm 0.002 \\
0.168 \pm 0.037 \\
0.215 \pm 0.005\end{array}$ & $\begin{array}{l}2.7 \\
2.2 \\
4.1 \\
3.2\end{array}$ & $\begin{array}{l}0.91 \pm 0.12 \\
1.10 \pm 0.08 \\
1.00 \pm 0.02 \\
1.16 \pm 0.04\end{array}$ & $\begin{array}{l}0.065 \pm 0.001 \\
0.094 \pm 0.006 \\
0.089 \pm 0.006 \\
0.112 \pm 0.001\end{array}$ \\
\hline $\begin{array}{l}\text { Greenhouse conditions, open bioreactors } \\
10 \% \text { ZM, } X_{0}=0.15 \\
20 \% \text { ZM, } X_{0}=0.15 \\
10 \% \text { ZM, } X_{0}=0.4^{\mathrm{b}} \\
20 \% \mathrm{ZM}, X_{0}=0.4\end{array}$ & $\begin{array}{c}0.113 \pm 0.017 \\
0.160 \pm 0.046 \\
0.153 \\
0.146 \pm 0.004\end{array}$ & $\begin{array}{l}6.1 \\
4.3 \\
4.5 \\
4.8\end{array}$ & $\begin{array}{c}0.83 \pm 0.01 \\
1.33 \pm 0.06 \\
1.32 \\
1.73 \pm 0.04\end{array}$ & $\begin{array}{c}0.043 \pm 0.008 \\
0.054 \pm 0.007 \\
0.077 \\
0.094 \pm 0.019\end{array}$ \\
\hline
\end{tabular}

a Rounded to nearest day.

b One run only, no replicate.

creased as the quantity of inoculum increased. In fact, the lowest growth rate $\left(\mu_{\max }=0.031\right)$ of all the experiments occurred in open bioreactors under controlled conditions in $20 \%$ Zarrouk medium inoculated with $0.4 \mathrm{~g} \mathrm{~L}^{-1}$, giving a biomass doubling time in excess of $22 \mathrm{~d}$ (Table I). Under greenhouse conditions the highest $\mu_{\max }$ value was $0.322 \mathrm{~d}^{-1}$ in closed bioreactors containing water supplemented with $20 \%$ Zarrouk medium and inoculated with $0.15 \mathrm{~g} \mathrm{~L}^{-1}$ of $S$. platensis biomass, giving a biomass $t_{\mathrm{d}}$ value of $2.2 \mathrm{~d}$, the most rapid growth rate of all the experiments (Table I). In the closed bioreactor greenhouse experiments $\mu_{\max }$ decreased when $X_{0}$ was increased to $0.4 \mathrm{~g} \mathrm{~L}^{-1}$, which might be caused by the high initial biomass concentration and could result in a more rapid depletion of nutrients. This hypothesis is reinforced by the fact that under greenhouse conditions $\mu_{\max }$ in both types of reactors was highest for cultures supplemented with $20 \%$ Zarrouk medium.

When all other factors were constant, except Zarrouk medium content, cultures in water supplemented with $10 \%$ Zarrouk medium reached the death phase before those supplemented with $20 \%$ Zarrouk medium. In the greenhouse experiments involving closed bioreactors $X_{\max }$ was $1.16 \mathrm{~g}$ $\mathrm{L}^{-1}$ after about $17 \mathrm{~d}$ (Fig. 1), while in the open bioreactors under the same conditions $X_{\max }$ was $1.73 \mathrm{~g} \mathrm{~L}^{-1}$ after about $23 \mathrm{~d}$ (Fig. 1). In both cases the biomass concentration decreased rapidly after reaching the maximum values. Under greenhouse conditions, the $X_{\max }$ value for the closed bioreactors appeared not to be very influenced by the inoculum, while in the open bioreactors $X_{\max }$ was higher when the inoculum was $0.40 \mathrm{~g} \mathrm{~L}^{-1}$. Independent of all other factors, the cultures supplemented with $10 \%$ Zarrouk medium presented lower biomass concentrations than those supplemented with $20 \%$ Zarrouk medium, which showed an average $X_{\max }$ value of $0.22 \mathrm{~g} \mathrm{~L}^{-1}$ for the closed bioreactors and $0.37 \mathrm{~g} \mathrm{~L}^{-1}$ for the open bioreactors (Figs. 1 and 2).

Regarding the maximum productivity $\left(P_{\max }\right)$, under controlled conditions in both the open and closed bioreactors this value was lower as the inoculum concentration increased (Table I). $P_{\max }$ in 


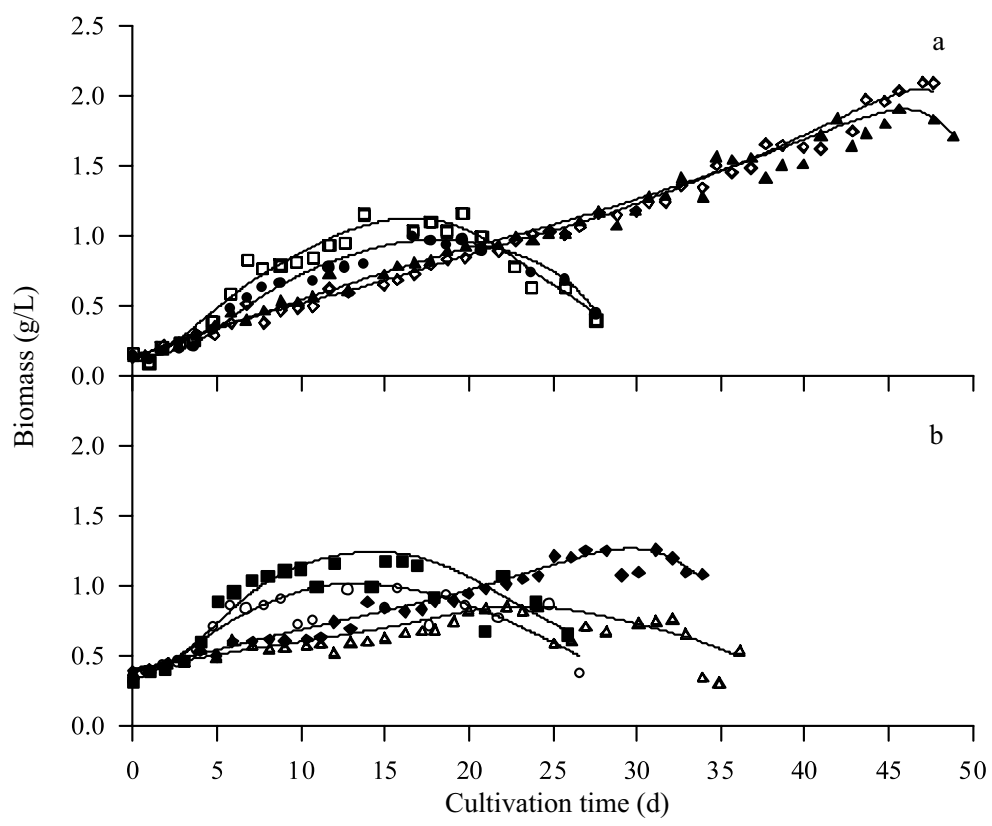

Fig. 1. Growth of Spirulina platensis strain LEB-52 under controlled conditions (CC) and greenhouse conditions (GC) in closed bioreactors containing water supplemented with different percentages of Zarrouk medium (ZM) and inoculated with different initial biomass concentrations $\left(X_{0}, \mathrm{~g} \mathrm{~L}^{-1}\right)$ of S. platensis. (a) CC, $10 \% \mathrm{ZM}, X_{0}=0.15$ $(\mathbf{\Delta})$; GC, $10 \% \mathrm{ZM}, X_{0}=0.15(\bullet) ; \mathrm{CC}, 20 \% \mathrm{ZM}, X_{0}=0.15(\diamond) ; \mathrm{GC}, 20 \% \mathrm{ZM}, X_{0}=0.15$ ( $\left.\square\right)$. (b) CC, $10 \% \mathrm{ZM}$, $X_{0}=0.40(\triangle) ; \mathrm{GC}, 10 \% \mathrm{ZM}, X_{0}=0.40(\bigcirc) ; \mathrm{CC}, 20 \% \mathrm{ZM}, X_{0}=0.40(\diamond) ; \mathrm{GC}, 20 \% \mathrm{ZM}, X_{0}=0.40(\mathbf{\square})$.

cultures inoculated with $0.15 \mathrm{~g} \mathrm{~L}^{-1}$ (Table I) was reached after about $7 \mathrm{~d}$ and then stabilized at $P=$ $0.04 \mathrm{~g} \mathrm{~L}^{-1} \mathrm{~d}^{-1}$, while in cultures inoculated with $0.4 \mathrm{~g} \mathrm{~L}^{-1} P_{\max }$ was reached after approx. $6 \mathrm{~d}$ and then declined to around $0.02 \mathrm{~g} \mathrm{~L}^{-1} \mathrm{~d}^{-1}$. Vonshak et al. (1982) pointed out that it is economically important to maintain high productivities as the biomass concentration increases, which is not always the case during the growth of photosynthetic microorganism because the increased number of cells at high biomass concentrations not only reduces the osmotic pressure of the medium due to nutrient depletion but also results in a 'shading effect' which decreases the light available to individual cells. Contrastingly, in the greenhouse experiments $P_{\max }$ increased for both types of bioreactors as the inoculum concentration increased, with $P_{\max }$ occurring within 8 days and reaching an average of $0.112 \mathrm{~g} \mathrm{~L}^{-1} \mathrm{~d}^{-1}$ for the closed bioreactors and $0.094 \mathrm{~g} \mathrm{~L}^{-1} \mathrm{~d}^{-1}$ for the open bioreactors. When the content of Zarrouk medium was raised from $10 \%$ to $20 \%$ the increase in $P_{\max }$ was more accentuated in the greenhouse experiments than under controlled conditions, indicating that, when S. platensis is grown under greenhouse conditions, supple- mentation of water with only $10 \%$ of Zarrouk medium could be a limiting factor for productivity. In the first 4 days of cultivation there was a decrease in the productivities of all the greenhouse cultures (Figs. 1 and 2). This was possibly due to the fact that the temperature reached $46{ }^{\circ} \mathrm{C}$ in the greenhouse during this period, a value above the maximum reported value for the growth of Spirulina (Tomaselli et al., 1993).

Analysis of variance indicated that environmental conditions were the most important factor influencing the magnitude of the maximum growth parameters, the exception being the maximum biomass concentration $\left(X_{\max }\right)$ in the open bioreactors where the concentration of Zarrouk medium was the most important factor.

Solar illuminance reached $2800 \mu \mathrm{mol} \mathrm{m} \mathrm{m}^{-2} \mathrm{~s}^{-1}$ in the greenhouse experiments, a value much higher than the $32.5 \mu \mathrm{mol} \mathrm{m}{ }^{-2} \mathrm{~s}^{-1}$ used in the controlled cultivations. The effects of the initial biomass concentration $\left(X_{0}\right)$ on the growth of $S$. platensis suggest a relationship between $X_{0}$ and light penetration into the interior of the cultures. Increased biomass density can provoke shading in the interior of the medium (Vonshak et al., 1982), and in 


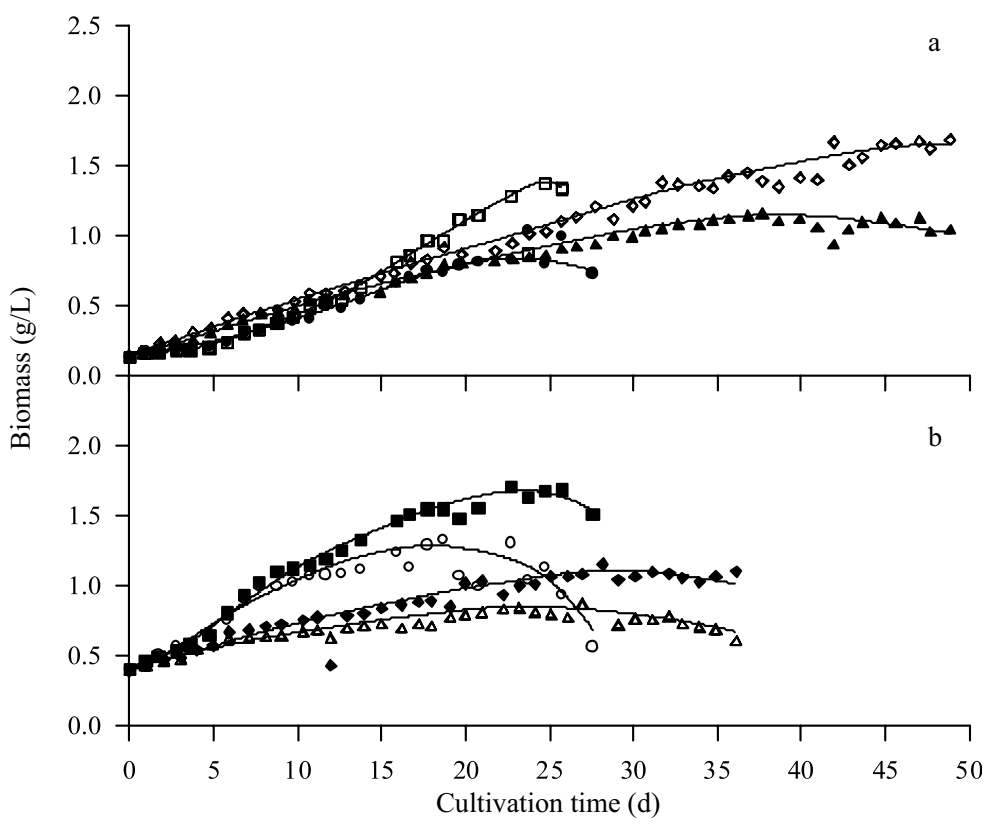

Fig. 2. Growth of Spirulina platensis strain LEB-52 under controlled conditions (CC) and greenhouse conditions (GC) in open bioreactors containing water supplemented with different percentages of Zarrouk medium (ZM) and inoculated with different initial biomass concentrations $\left(X_{0}, \mathrm{~g} \mathrm{~L}^{-1}\right)$ of S. platensis. (a) CC, $10 \% \mathrm{ZM}, X_{0}=0.15(\mathbf{\Delta})$; GC, $10 \% \mathrm{ZM}, X_{0}=0.15(\bullet)$; CC, 20\% ZM, $X_{0}=0.15(\diamond)$; GC, 20\% ZM, $X_{0}=0.15(\square)$. (b) CC, $10 \% \mathrm{ZM}, X_{0}=$ $0.40(\triangle) ; \mathrm{GC}, 10 \% \mathrm{ZM}, X_{0}=0.40(\bigcirc) ; \mathrm{CC}, 20 \% \mathrm{ZM}, X_{0}=0.40(\diamond) ; \mathrm{GC}, 20 \% \mathrm{ZM}, X_{0}=0.40(\mathbf{\square})$.

the high-luminosity greenhouse experiments shading could have reduced the penetration of light and decreased photoinhibition (Lu and Vonshak, 1999; Chanawongse et al., 1994), while under the $32.5 \mu \mathrm{mol} \mathrm{m} \mathrm{m}^{-2} \mathrm{~s}^{-1}$ used under controlled conditions light could have been a limiting factor at high $X_{0}$ values due to photolimitation (Chojnacka and Noworyta, 2004).

In the greenhouse experiments temperatures varied from 9.4 to $46{ }^{\circ} \mathrm{C}$, with the lowest temperatures generally occurring at night. Although the optimum growth temperature for Spirulina has been reported to be $30-38^{\circ} \mathrm{C}$ (Belay, 1997), temperature variation during the light/dark cycle may result in higher productivities due to a drop in dark-phase respiration as a result of low temperature. Torzillo and Vonshak (1994) reported that the dark-phase respiratory activity of Spirulina increases with increasing temperature, reaching a maximum at $45^{\circ} \mathrm{C}$ and consuming up to $35 \%$ of the biomass produced during the light-phase (Tor- zillo et al., 1991). In the controlled cultures maintained constant at $30^{\circ} \mathrm{C}$ dark-phase respiration would have been higher than in the greenhouse experiments, leading to higher respiration and hence lower net productivity.

The temperature and illuminance levels, and the variation in these factors, to which the greenhouse cultures were exposed, resulted in increased growth in both reactor types. However, this high growth rate appears to have stressed the cells and produced an earlier death phase (Figs. 1 and 2). This effect was more accentuated in the closed bioreactors where temperature change was the result of incident solar radiation and conduction through the glass walls of the bioreactors, resulting in high temperature in the liquid medium and thus in an unfavourable micro-environment for S. platensis. In the open bioreactors high temperatures were mitigated because heat flux between the culture medium and the atmosphere was facilitated by convection. 
Bailey J. E. and Ollis D. F. (1986), Biochemical Engineering Fundamentals, $2^{\text {nd }}$ ed. McGraw-Hill, Singapore.

Belay A. (1997), Mass culture of Spirulina outdoors The Earthrise farms experience. In: Spirulina platensis (Arthrospira). Physiology, Cell-Biology and Biotechnology (Vonshak A., ed.). Taylor and Francis, London, pp. 131-158.

Box G. E. P., Hunter W. G., and Hunter J. S. (1978), Statistics for Experiments. John Willey and Sons, New York.

Chanawongse L., Lee Y. K., Bunnag B., and Tanticharoen M. (1994), Productivity of the cyanobacterium Spirulina platensis in cultures using sunlight. Biores. Technol. 48, 143-148.

Chen F., Chen H., and Gong X. (1997), Mixotrophic and heterotrophic growth of Haematococcus lacustris and rheological behavior of the cell suspensions. Biores. Technol. 62, 19-24.

Chojnacka K. and Noworyta A. (2004), Evaluation of Spirulina sp. growth in photoautotrophic, heterotrophic and mixotrophic cultures. Enzyme Microbial Technol. 34, 461-465.

Costa J. A. V., Linde G. A., and Atala D. I. P. (2000), Modelling of growth conditions for cyanobacterium Spirulina platensis in microcosms. World J. Microbiol. Biotechnol. 16, 15-18.

Costa J. A. V., Colla L. M., Duarte Filho P., Kabke K., and Weber A. (2002), Modelling of Spirulina platensis growth in fresh water using response surface methodology. World J. Microbiol. Biotechnol. 18, 603-607.

Costa J. A. V., Colla L. M., and Duarte Filho P. F. (2004), Improving Spirulina platensis biomass yield using a fed-batch process. Bioresource Technol. 92, 237-241.

Grima E. M., Sevilla J. M. F., Pérez J. A. S., and Camacho F. G. (1996), A study on simultaneous photolimitation and photoinhibition in dense microalgal cultures taking into account incident and averaged irradiances. J. Biotechnol. 45, 59-69.

Hase R., Oikawa O., Sasao C., Morita M., and Watanabe Y. (2000), Photosynthetic production of microalgal biomass in a raceway system under greenhouse conditions in Sendai City. J. Biosci. Bioeng. 89, 157-163.

Hosaka K., Hioki T., Furuune H., and Tanishita K. (1995), Augmentation of microalgae growth due to hydrodynamic activation. Energy Convers. Manage. 36, $725-728$.

Jiménez C., Cossío B. R., and Niell F. X. (2003), Relationship between physicochemical variables and productivity in open ponds for the production of Spirulina: a predictive model of algal yield. Aquaculture 221, $331-345$.
Lu C. and Vonshak A. (1999), Photoinhibition in outdoor Spirulina platensis cultures assessed by polyphasic chlorophyll fluorescence transients. J. Appl. Phycol. 11, 355-359.

Radmann E. M., Reinehr C. O., and Costa J. A. V. (2007), Optimization of the repeated batch cultivation of microalga Spirulina platensis in open raceway ponds. Aquaculture 265, 118-126.

Richmond A., Wu Z. C., and Zarmi Y. (2003), Efficient use of strong light for high photosynthetic productivity: interrelationships between the optical path, the optimal population density and cell growth inhibition. Biomol. Eng. 20, 229-236.

Schmidell W., Lima A. U., Aquarone E., and Borzani W. (2001), Biotecnologia Industrial, Vol. 2. Edgard Blücher LTDA, São Paulo.

Tomaselli L., Giovannetti L., and Torzillo G. (1993), Physiology of stress response in Spirulina spp. Bull. Inst. Oceanogr. Monaco 12, 65-75.

Torzillo G. and Vonshak A. (1994), Effect of light and temperature on the photosynthetic activity of the cyanobacterium Spirulina platensis. Biomass Bioen. 6, 399-403.

Torzillo G., Pushparaj B., Bocci F., Balloni W., Materassi R., and Florenzano G. (1986), Production of Spirulina biomass in closed photobioreactors. Biomass 11, $61-74$.

Torzillo G., Sacchi A., and Materasi R. (1991), Temperature as an important factor affecting productivity and night biomass loss in Spirulina platensis grown outdoors in tubular photobioreactors. Biores. Technol. 38, 95-100.

Travieso L., Hall D. O., Rao K. K., Benítez F., Sánchez E., and Borja R. (2001), A helical tubular photobioreactor producing Spirulina in a semicontinuous mode. Int. Biodeter. Biodegr. 47, 151-155.

Vonshak A. (1997), Outdoor mass production of Spirulina: The basic concept. In: Spirulina platensis (Arthrospira). Physiology, Cell-Biology and Biotechnology (Vonshak A., ed.). Taylor and Francis, London, pp. 79-100.

Vonshak A. and Richmond A. (1988), Mass production of the blue-green alga Spirulina: An overview. Biomass 15, 233-247.

Vonshak A., Abeliovich A., Boussiba S., Arad S., and Richmond A. (1982), Production of Spirulina biomass: effects of environmental factors and population density. Biomass 2, 175-185.

Zarrouk C. (1966), Contribution à l'étude d'une cyanophycée. Influence de divers facteurs physiques et chimiques sur la croissance et photosynthese de Spirulina maxima Geitler. Ph.D. Thesis, University of Paris. 